\title{
«Jeg har aldri spurt om å kunne slutte selv»» En kvalitativ studie av en gruppe jenters vei mot frafall i videregående skole
}

\author{
Sissel Elisabeth Edvardsen ${ }^{1}$, Hege Hovland ${ }^{2}$ og Anne Brita Thorød ${ }^{3}$ \\ 1) MA Folkehelse, Grimstad kommune, Helse og omsorgssektoren \\ 2) MA Psykisk helsearbeid, Torridal ungdomsskole, Kristiansand \\ 3) Universitetet i Agder, Fakultet for helse-og idrettsvitenskap, Grimstad
}

Korrepondanse: Anne Brita Thorød, Universitetet i Agder, Fakultet for helse- og idrettsvitenskap, Postboks 509, 4898 Grimstad Epost: anne.b.thorod@uia.no Telefon $37233753 / 99232352$

\begin{abstract}
SAMMENDRAG
I denne artikkelen utforsker vi skolehistorien til jenter som har avbrutt sin videregående utdanning, og er registrert under Oppfølgingstjenestens kode OTSY. Denne koden indikerer at de er for syke til å gjennomføre skolegangen. Studien har en kvalitativ, utforskende design med en induktiv tilnærming. Intervjuene ble gjennomført ved hjelp av Livslinje-metode, med noen supplerende spørsmål i tillegg. De fleste jentene beskriver svake relasjoner til både skolekamerater og lærere på barneskolen. Noen av dem har erfaring med mobbing og de beskriver en skole uten evne til å håndtere problemene og arbeide for et inkluderende skolemiljø. Når de når videregående opplæring har de høyt fravær og de fleste blir oppfordret til å avbryte skolegangen, delvis begrunnet $\mathrm{i}$ at de ikke skal tape et år av Ungdomsretten til videregående opplæring. Funnene er diskutert i lys av resiliensteori og et bio-økologisk perspektiv.
\end{abstract}

\section{Edvardsen SE, Hovland H, Thorød AB. "I never asked to quit school myself". A qualitative study of a group of girls' path to drop out of upper secondary school. Nor J Epidemiol 2019; 28 (1-2): 69-77.}

\section{ENGLISH SUMMARY}

In this article we explore the school history of girls who are dropping out from upper secondary school, recorded with mental problems. The study has a qualitative, exploratory design with an inductive approach. Interviews were conducted with life-line method, with some supplemental questions. Most of the girls experience weak relations to both school-peers and teachers in primary school. Some of them are bullied and describe a school without capability to deal with the problems and work for an including school environment. When they reach upper secondary school they have a high absence rate and most of them are requested to terminate school, partly due to the risk of losing part of their statutory right to upper education. The findings are discussed in resilience- and bio-ecological perspectives.

This is an open access article distributed under the Creative Commons Attribution Licence, which permits unrestricted use, distribution, and reproduction in any medium, provided the original work is properly cited.

\section{INNLEDNING}

Hensikten med denne studien er å få mer kunnskap om hvilke erfaringer en gruppe jenter har gjennom skoleløpet og som har bidratt til at de avbryter videregående opplæring. Det er en generell bekymring for frafallet $\mathrm{i}$ den videregående skolen. $79 \%$ av jentene fullfører videregående skole i løpet av 5 år, mens bare $68 \%$ av guttene fullfører. Til sammen får vi en fullføringsrate på 73\% (Barne-, ungdoms- og familiedirektoratet, 2018). Man regner at det både er samfunnsmessige og individuelle konsekvenser av manglende fullført videregående opplæring. Det er samfunnsøkonomisk kostbart, og i tillegg vet vi at ungdom uten videregående opplæring blant annet risikerer dårligere psykisk helse og å komme dårlig ut når det gjelder fremtidig jobb og livsløpsinntekt (Høie \& Thorød, 2018; Lillejord et al., 2015; Croninger \& Lee, 2001; De Ridder et al., 2013; Falch et al., 2010).

Studier som leter etter årsaker til frafall i videregående skole er ingen mangelvare. Det er heller ingen entydige svar på dette. Både strukturelle og individuelle forhold spiller inn. Lillejord et al. (2015) og Rogstad \& Reegård (2016) har gjort grundige gjennomganger av tilgjengelig litteratur på dette feltet. Og $\mathrm{i}$ en studie av drøyt 2000 16-åringer i videregående opplæring finner Frostad et al. (2015) to forhold i skolekonteksten som hadde stor påvirkning på intensjonen om å avbryte skolegangen, nemlig støtte fra lærere og ensomhet. Med dette utgangspunktet formulerer vi følgende problemstillinger:

- Hvordan opplever en gruppe jenter at de har blitt ivaretatt av lærere og andre voksne i skolen gjennom skoleløpet fram mot avbrudd?

- Hvordan kan skolesystemet generere resiliens som forebygging av skoleavbrudd?

\section{TEORETISK GRUNNLAG}

Det kan synes hensiktsmessig å legge et bio-psykososialt perspektiv til grunn når vi studerer ungdom som avbryter skolegangen. I sin litteraturgjennomgang av 
årsaker til frafall viser Lillejord et al. (2015) til flere årsaker som kan knyttes til et slikt perspektiv, fra individfaktorer hos den enkelte elev, til utfordringer knyttet til familie og nettverk samt kontekstuelle og strukturelle forhold relatert til skolesystem, lokal- og makrosamfunn. For denne modellen tar vi utgangspunkt i Bronfenbrennes utviklingsøkologisk perspektiv (Bronfenbrenner, 2005; Ungar et al., 2013). Bronfenbrenners utviklingsøkologiske modell (Bronfenbrenner, 1979) er godt kjent og brukes i mange sammenhenger. Den opprinnelige modellen tegnes som konsentriske sirkler rundt individet i mikrosystemet som også inkluderer personer som møtes ansikt til ansikt. I mesosystemet finner vi bånd og samspill mellom personer og ulike arenaer. I eksosystemet deltar sjelden individet selv, men det har betydning for liv og utvikling, mens makrosystemet viser til struktur og kultur i storsamfunnet (Bø and Schiefloe, 2007). Alle disse systemene og i særlig grad interaksjonene mellom dem vil på forskjellige måter virke inn på barn og unge i deres utvikling mot voksenlivet (Bronfenbrenner, 1979). Bronfenbrenner utviklet stadig modellen basert på sin videre forskning. Chronosystemet ble lagt til og dette tar inn de dynamiske og pågående transaksjoner som utspilles mellom individ og kontekst (Bronfenbrenner, 1986; Schoon, 2012). Måten barnets biologiske disposisjoner samvirker med krefter i omgivelsene ble tydeliggjort og modellen ble senere kalt en bio-økologisk modell (Bronfenbrenner, 2005; Berk, 2018). Det må presiseres at ingen del av modellen har forrang foran en annen, men bygger på at de forskjellige elementene i modellen virker sammen $i$ et komplekst samspill (Ungar et al., 2013).

Utviklingsforskning har tradisjonelt fokusert på mikronivået og individuelle forhold. Betydning av omgivelser og nærmiljø har imidlertid fått et stadig større fokus (Beyers et al., 2003; Thorød, 2010; Ungar et al., 2013). Med basis i årtiers utviklingsforskning konkluderer den kanadiske resiliensforskeren Michael Ungar med at barns positive utvikling er primært et resultat av støttende omgivelser som utstyrer barn med potensiale til å gjøre det godt i livet. Derfor bør en studere konteksten først og deretter barnet (Ungar, 2011). Fokus på resiliens, motstandskraft eller robusthet er viktig i den forstand at det sier noe om hvordan et barn er i stand til å møte de påkjenningene som kommer gjennom oppveksten. I en tidlig fase ble resiliens sett som en egenskap ved individet (Ungar et al., 2013). Imidlertid synliggjorde forskningen tidlig at $i$ tillegg til de individuelle forholdene måtte en trekke inn egenskaper knyttet til familie og nærmiljø (Masten and Garmezy, 1985), og at resiliens var en dynamisk prosess der disse forholdene virker inn på hverandre (Schoon and Bynner, 2003). Helmen Borge (2010) står i samme tradisjon når hun konkluderer med at «sosiale miljøer kan «skru på» en genetisk sårbarhet eller «skru av» en genetisk styrke». Dette er vesentlig å løfte fram når tidens rådende paradigme har et sterkt preg av biologi og genetikk (Ekeland, 2011).

\section{Metode}

I denne artikkelen setter vi fokus på jenter som avbryter videregående opplæring. Vi bygger på et kvalitativt datamateriale fra Agder, innhentet av to masterkandidater $i$ hhv. folkehelsevitenskap og psykisk helsearbeid. I juni 2015 ble følgende vedtak gjort i Aust-Agder fylkesting:

«I forbindelse med prosjektet «Skolen som arena for barn og unges psykiske helse» ønskes å kartlegge et utvalg av jentene som er droppet ut av skolen, og som har psykiske vansker. Gjerne fra de kommunene som ligger høyest på statistikken.» (FT-sak 15/35). Dette ble utgangspunkt for mastergradsprosjektene til kandidatene Edvardsen og Hovland. Begge disse oppgavene setter fokus på mestring og mestringstro. Det kommer fram at informantene har hatt store utfordringer både i hjem, nettverk og skole, noe som har lagt grunnlag for deres forhold til skolegangen og senere skoleavbrudd (Edvardsen, 2017; Hovland, 2017).

Utvalget i studien er jenter $i$ alderen 16-20 år, som har avbrutt videregående opplæring, en eller flere ganger, registrert med kode OTSY, siste gang i skoleåret 2015-2016. Koden står for: «Er syk/i institusjon» og ett av kriteriene er: - forhold ved eleven som hindrer vedkommende fra å nyttiggjøre seg opplarings- eller jobbtilbud. Det kan vere fysisk eller psykisk sykdom, rusbruk, sosiale og/eller emosjonelle vansker (Utdanningsdirektoratet 2016). Intervjuene ble gjennomført høsten 2016. Jentene kommer fra kommuner av ulik størrelse, representerer by og bygd, og ble rekruttert gjennom oppfølgingstjenesten og utdanningsavdelingene i fylkene. Dette resulterte i en liste med 11 navn på jenter som sa seg villig til å bli med i studien. Jentene ble kontaktet på telefon hvor de ble informerte om studien og dens hensikt. For de som ønsket å bli med videre i studien, ble tidspunkt for intervju avtalt. To av de navngitte jentene trakk seg fra studien allerede i starten, en trakk seg dagen før avtalt intervju og den siste trakk seg ett par timer før avtalt intervju, på grunn av helsemessige årsaker.

Jentene som ønsket å delta i undersøkelsen, hadde alle vokst opp i etnisk norske hjem, men en av jentene var adoptert tidlig i livet til Norge. Dette resulterte i et utvalg på 8 jenter når vi inkluderer prøveintervjuet. Jenta som deltok i prøveintervjuet faller inn under kriteriene for studien, da hun har avsluttet videregående opplæring to ganger, siste gang i skoleåret 2015-2016. Alle jentene var høsten 2016 tilbake i et utdanningsløp, jobbet eller var i kontakt med NAV.

I denne studien falt valget på en intervjuform som vi fant lite beskrevet i metodelitteraturen, men best eksemplifisert i artiklene Portraits of Life: Patterns of Events Over the Lifespan (Schroots \& Assink, 2005) og Lifelines of Women in Jail as Self-Constructed Visual Probes for Life History Research (Hanks \& Carr, 2008). Metoden er kalt Livslinje-metode (LIM), og ble tilpasset vårt prosjekt. Et viktig aspekt ved livslinjemetoden er at både fortid og fremtid skal komme frem 
(Schroots \& Assink, 2005). Dette var også bakgrunnen for at vi valgte denne metoden, at vi ønsket å få ett mer helhetlig innblikk i jentenes livshistorie. Livslinje som intervjumetode er blitt brukt med flere hensikter tidligere, blant annet for å oppmuntre informantene til å se hendelser i livet deres som en del av deres historie og for å markere vendepunkter i livet og skape mening av disse vendepunktene (Hanks \& Carr, 2008).

I intervjuet ble det brukt ett blankt ark i en A3 blokk som hjelpemiddel. På denne tegnet vi en gjennomgående linje (livslinje). På livslinjen fylte informantene inn fødselsdato, hendelser i livet deres fram til i dag og hva de så for seg eller ønsket for fremtiden. Jentene valgte selv hva de syntes var viktig å trekke fram ved å skrive dette på tidslinjen. De fikk på den måten være med på å styre samtalen. Ved å strukturere intervjuene på denne måten, fikk vi også tilgang på informasjon vi selv kanskje ikke hadde tenkt over at var viktig. Når jentene selv skrev inn hendelser fra eget liv, åpnet det opp for andre spørsmål og samtaler som muligens ikke ville funnet sted dersom vi hadde definert spørsmålene på forhånd.

Intervjuene ble foretatt i kjente omgivelser for jentene, i jentenes hjem eller på skolen de nå tilhører. Intervjuene ble avtalt $\mathrm{i}$ god tid $\mathrm{i}$ forveien og det var satt av romslig med tid til gjennomføringen. Før intervjuet startet fikk jentene muntlig og skriftlig informasjon om studien, hva datamaterialet skulle brukes til, samt at de skrev under på samtykkeskjema.

Samtlige intervju ble tatt opp digitalt og transkribert ordrett kort tid etter at de var gjennomført. Da datamaterialet besto av både en visuell kilde, tidslinjeskjemaet og intervjuutskrifter ble disse først analysert hver for seg, for så å ses som en enhetlig kilde. Intervjuutskriftene ble nøye gjennomlest og kodet. Livslinjene ble gjennomgått for å finne sentrale hendelser og brekkpunkt i livsløpet som igjen førte oss tilbake til intervjuutskriftene for å få utvidet forståelse av hva informantene la i disse hendelsene. Sentrale hendelser og opplysninger basert på kodingen ble satt inn i matrise med en kolonne for hver informant. Dette gjør det mulig å se mønster i materialet samtidig som det særegne for hver enkelt jente ble tydeliggjort. Den endelige utskrivingen av funnene ble gjort som en hermeneutisk prosess der arbeid med intervjuutskrifter, livsløpsskjema og matrise utgjorde enkeltelementer i veksling med et helhetsbilde.

Innsamlet datamaterialet er behandlet konfidensielt og i henhold til forskningsetiske retningslinjer. Prosjektet er del av et større prosjekt ved Universitetet i Agder og gjennom dette godkjent av Regional etisk komite (REK, ref. 2015/2431). Deltagernes anonymitet er ivaretatt ved å endre sentrale opplysninger om informantene, og ved å begrense tilgangen til informasjon om hvilke jenter som tilslutt ble med i studien. Det blir brukt navn på informanter der dette er hensiktsmessig for framstillingen. Alle navn som er brukt i artikkelen er fiktive.

\section{KARAKTERISTIKA VED INFORMANTENE}

Alle informantene $\mathrm{i}$ dette materialet har vært $\mathrm{i}$ kontakt med psykisk helsetjeneste i løpet av skolegangen. De psykiske utfordringene som ble beskrevet var knyttet til angst, depresjon, ADHD og mer udefinerte problemer som hodepine og søvnvansker. Fire av sju hadde somatiske utfordringer i tillegg til de psykiske. Sammenhengen mellom disse utfordringene ligger utenfor rammen for denne artikkelen, men med humanistisk syn på psykisk lidelse er det forventet at det fysiske og psykiske virker inn på hverandre (Haugsgjerd et al., 2009). Flere av jentene har vært utsatt for mobbing gjennom skoleløpet, og det er varierende om de har hatt nære venner i oppveksten. Den typiske skolehistorien med noen variasjoner er ei jente som har gått gjennom grunnskolen med svak relasjon til kontaktlærer og medelever. Hun har blitt mobbet uten at dette ble tatt tak i av skolen. I ungdomsskolen utviklet hun psykiske symptomer, men (flere) hadde også somatisk diagnose. Sammen førte dette til høyt fravær. Deretter startet hun opp på videregående skole med motivasjon til å komme gjennom, men fraværet gjorde det vanskelig å følge med på de faglige kravene og det endte med skoleavbrudd.

De fleste jentene kommer fra familier der en eller begge foreldre har høyere utdanning. Mest karakteristisk er det at mødrene er høyere utdannet enn fedrene. Relasjonen til mor beskrives i hovedsak som god og støttende, mens fedrene beskrives med større variasjon. Noen fedre hadde egne utfordringer som f.eks. rusproblematikk og generelt ble fedrene beskrevet som mindre betydningsfulle for jentene enn det mor har vært.

\section{RELASJONER OG TILHØRIGHET I GRUNNSKOLEN}

En god relasjon mellom lærer og elev som er etablert tidlig i skoleløpet synes å ha god effekt på hele skoleløpet (Huges, 2012; Sabol \& Pianta, 2012). Det viser seg imidlertid at elevers opplevelse av støtte fra lærer og tilhørighet synker med alder (Federrici \& Skaalvik, 2013). I denne sammenhengen er det interessant å se at flere av våre informanter i liten grad husker sine kontaktlærere fra barneskolen.

"Jeg husker ikke hvem det var" svarte ei av jentene da hun ble spurt om kontaktlæreren sin på barneskolen. Ei av de som husker kontaktlæreren sin forteller at denne læreren prøvde å hjelpe henne så godt hun kunne, men at denne hjelpen begrenset seg til å kun tilpasse skolearbeidet hennes. Hun hjalp lite til når det kom til det sosiale:

[hun var] egentlig veldig bra, veldig forståelsesfull dame. Hun var veldig flink til å skille at barn er ulike og noen trenger mer av det og sånne ting. Så hun hjalp til så godt hun kunne, men det var jo det med elevene, at det hjalp jo ikke om jeg fikk til skolearbeidet. Det var jo fortsatt at jeg ikke hadde noen venner i friminuttet. 
Her synliggjøres det at selv om informanten opplever støtte fra læreren er det ikke gitt at tilhørigheten til skolen er like sterk når relasjonen til de jevnaldrende ikke er på plass. Skaalvik \& Skaalvik (2013) legger vekt på at tilhørighet handler om å gi omsorg, motta omsorg og å føle seg akseptert av de rundt seg. Dette gjelder i alle relasjoner i skolen. Djupedal-utvalget slår fast at «faglig læring må kobles og integreres med sosial læring, de er ikke motsetninger» (NOU 2015:2). At dette ikke alltid er en realitet i skolen kommer særlig fram hos de jentene som har de sterkeste fortellingene om mobbing.

Dina opplevde at hun ble mobbet gjennom hele barneskolen. Hun forteller at dette ble tatt opp med skolen flere ganger uten respons:

Intervjuer: - - laererne på skolen, eller skolen generelt, følte du at de gjorde noe for å hjelpe deg? [-] Prøvde de noe eller ingenting?

Dina: Nei, ikke egentlig, jeg folte bare mer at det var min feil så hvorfor skulle de gjøre noe med det?

Dette er en erfaring Dina deler med Gro. Gro fikk tidlig diagnose ADHD og forteller om hvordan ryktet om hennes atferd fulgte henne fra barnehagen og over i skolen. Dette førte til isolasjon og utestengning, og gjorde at hun aldri kom inn i vennerelasjoner. Også mange av lærerne syntes å dele barnas syn på Gro:

Jeg var ikke akkurat den ungen som ikke sa noe ting heller. Jeg tok igjen, og da tok jo de igjen og det gikk jo i en ganske vond sirkel. Voksne var ikke noe vits å si ifra til, de brydde seg ikke. De enset det ikke en gang. [. . .] Det var laererne, de som var i friminuttet og sånne ting. Det var ikke vits å si fra-fordi, da var det bare «ja men du begynte» og så... jeg fikk jo kjeft når jeg var på foreldremøter om at jeg måtte si fra til voksne. Og igjen, så hørte ikke de etter og da var det jo ingen der til å hjelpe.

Begge disse jentene sitter igjen med en følelse av at lærerne oppfatter at jentene har skyld i sin egen mobbesituasjon. Selv om de også forteller om lærere de hadde positiv relasjon til førte det ikke til at det ble satt fokus på det psykososiale miljøet. Det synes som de jentene som har klarest minner om lærerne sine på barneskolen er de som har mobbeerfaringer. Her husker de at de voksne sviktet, men de husker også at det var noen lærere som forsøkte å ta vare på dem. De jentene som beskriver skolen uten spesielle vansker har vagere forestillinger om hvordan lærerne var mot dem.

For enkelte ble ungdomsskolen en ny start, men jentenes forventninger er varierte. Selv om det er delte meninger om kontaktlærerne er de generelt mer positive. De fleste husket nå kontaktlæreren sin og fortalte varmt om han/henne.

Egentlig så var det bare det at han viste at han brydde seg om hvordan alle hadde det. Han var egentlig veldig flink, han var veldig til å se hver enkelt person og han var der og prøvde faktisk.
Dette er et utsagn som synliggjør beskrivelsene informantene ga om sine tidligere lærere. Jentene forteller om positive egenskaper hos kontaktlærerne som at de brydde seg om hvordan alle hadde det, viste omsorg, de så hver enkelt og tilpasset seg dem.

En av jentene trakk frem at kontaktlæreren var ok, fordi vedkommende ikke «var oppå meg hele tiden, og skulle rakke ned på meg». Dette forteller antakelig mer om jentas tidligere lærer-erfaringer enn det beskriver en god elev-lærer-relasjon. Ett par av jentene hadde ikke positive opplevelser knyttet til kontaktlæreren sin, men heller opplevelser av negativ art. En av jentene fortalte at «kontaktloereren min utmerket seg veldig negativt. Det var hun som kom med de «flotte» kommentarene om at jeg ikke kunne noe...»

I løpet av ungdomsskoletiden ble jentenes individuelle utfordringer mer synlige. Både fysiske og psykiske symptomer manifesterer seg og forstyrrer skolehverdagen i form av blant annet høyt fravær. Selv om både fysiske og psykiske plager kan ses som forhold ved individet, kan dette også forstås i sammenheng med de relasjonelle utfordringene jentene har fortalt om tidligere i skoleløpet. Imidlertid kommer det fram at noen av dem så vanskene sine $\mathrm{i}$ et relasjonelt perspektiv. Ei jente forteller at fraværet hennes økte $i$ perioder når faren hennes drakk mye. En annen peker på at medelevers spørsmål om hvorfor hun var borte fra skolen gjorde det ekstra vanskelig å komme tilbake, noe som førte til en negativ fraværsspiral.

I begynnelsen [av ungdomsskolen] hadde jeg bedre karakterer, og så gikk det bare nedover. (-) første del av 8ende hadde jeg 5 i matte, tror jeg.

Da jeg gikk ut av 10ende så hadde jeg 2. [-] Også var det sånn at jeg kunne ikke konsentrere meg og jeg var så sliten og fikk ikke sove og da havnet jeg så langt bak $i$ alt.

\section{(-) Jeg tror jeg hadde en måned fravar hver termin.}

Jeg fant aldri en plass [på skolen] der jeg følte meg komfortabel og hadde det bra. Men (-) på slutten av åttende klasse... så blei jeg ekstremt deprimert og var borte fra skolen i 2 måneder. (-) 10. klasse var jeg mer til stede, men åttende og niende var jeg veldig mye borte.

Dette fraværet kunne resultere i svakere skoleprestasjoner som predikerte et mønster som ble tydeligere når de gikk over i videregående skole.

\section{FORHOLD TIL EKSTERNE TJENESTER}

Ved overgangen til ungdomsskolen opplevde de fleste jentene at mobbingen er over og at de har fått bedre relasjoner til lærerne sine. Nå har imidlertid flere av jentene fått så store andre vansker at skolen ser behov for å sette inn flere støttetiltak og hjelpetjenester. Dette blir ikke alltid opplevd positivt. Bente forteller dette:

Bente: [I 9. klasse] - jeg ble jo, jeg var veldig mye syk den vinteren. Og så ... jeg var syk så jeg kom 
ikke på skolen, og etterpå det ble det bare mye vanskeligere å gå på skolen. Og så var det så mange som ble blandet inn. Jeg vet ikke, hva kalles de folkene?

Intervjuer: Tenker du kontaktloerer, og PPT og sånne ting?

Bente: Ja, jeg skjønte ikke hvorfor de skulle dra inn så mange (-). Det hjelper ikke meg noe-jeg mener jeg liker ikke ukjente folk liksom og når de liksom vet alt om meg og alt sånn. Det hadde vart mye bedre hvis det bare hadde vart noen fä.

De fleste av jentene hadde på ett eller flere tidspunkt blitt behandlet i ABUP eller av andre eksterne terapeuter eller psykologer. Det går fram av jentenes fortellinger at det hadde hjulpet dem i mindre grad, og at det til tider kunne virke mot sin hensikt. Dette var med tanke på at de mistet tid på skolen og derfor hang mer etter både faglig og sosialt.

Vi var jo borte til noen samtaler og sånne ting, aldri noe som hjalp, aldri noe. Det hadde ikke noe betydning for meg annet at det tok tid av skolen og sånne ting.

Det synes imidlertid som de støttepersonene og tiltak som var tilknyttet skolen selv var til hjelp. Noen fikk spesialpedagogiske tiltak eller praktisk tilrettelegging. En hadde nytte av utplassering $i$ barnehage en til to dager i uka, mens en annen jobbet i skolekantina. Det var ikke bare selve jobben hun likte: «Vi hadde ei som dreiv skolekantina som jeg jobbet $i$ som var helt fantastisk». Det var denne personen hun pekte på som mest betydningsfull i ungdomsskoletiden. For Bente var det assistenten hun fikk som ble den viktigste:

«Hun var assistent. Og vi ble veldig gode venner. Og siden jeg ikke ville sitte inne $i$ klassen kunne jeg sitte på ett eget rom og lese og gjøre sånn skoleting. - For det var hun jeg var sammen med hver dag.»

Andre hentet støtte fra helsesøster eller skolens miljøterapeut. Slik kan det se ut som de tiltakene som ligger nærmest jentene er de som oppleves å være til mest hjelp.

\section{VEIEN INN OG VEIEN UT AV VIDEREGÅENDE SKOLE}

Retten til videregående opplæring står sterkt, og en kan si at det ligger en disiplinerende kraft i dette som gjør at de aller fleste ungdommer søker seg inn selv om de er skolelei, sliter med manglende motivasjon eller har andre vansker. Dette kan bidra til at valg av studieretning ikke er helt gjennomtenkt hos enkelte av jentene. Det er også usikkert om de har fått den rådgiving de trengte da de søkte seg inn. Noen av jentene hadde søkt seg inn på «Musikk, dans, drama» der programfagene kom i tillegg til de studiespesialiserende fagene. Altså ble skolen tyngre med større krav til frammøte enn om de hadde valgt en annen studieretning. For noen medførte overgangen til videre- gående at de måtte flytte på hybel og dermed mistet den daglige støtten fra familien og nettverket.

For de fleste jentene fortsatte mønsteret med høyt fravær: "Jeg gjør det jo egentlig greit på skolen, men jeg klarer bare ikke å møte opp". De forteller om at de ønsket å gå på skolen, men de kjente på mye press og forventninger de ikke mestret. Dette presset var mer knyttet til det sosiale miljøet enn det skolefaglige. Alle uttrykte likevel et ønske om å gjøre det bra og å gå på skolen. "Jeg ville jo fortsette, men la merke til at jeg ikke greide det", er en annen jentes beskrivelse av hverdagen på videregående.

Jentene forteller at det ble satt $\mathrm{i}$ gang tiltak fra skolens side når de syntes dagene ble for vanskelige og fraværet ble stort. Tiltakene som ble satt i gang var blant annet kortere skoledager og færre fag; «de prøvde, jeg fikk kortere skoledager, men det hjalp $i k k e »$. De fortalte lite om rene faglige tiltak eller tiltak som gikk på det sosiale.

Ser en på tiden jentene gikk på videregående skole, og da må en ta med at noen av disse jentene sluttet etter kort tid, så er det kun halvparten som nevner kontaktlæreren fra videregående. De fleste kontaktlærerne gjorde seg lite bemerket, men ett par av jentene fortalte om positive opplevelser. En av jentene fortalte om hjelp fra sin kontaktlærer, som gjorde at hun kom seg igjennom og besto et år på videregående skole, før hun igjen sluttet på skolen det neste året.

Hun kjørte liksom innom, så hun kunne hente meg på vei til skolen, så jeg fikk sitte på med henne. Og hun tok av og til med prøver og sånn hjem, så at jeg kunne gjøre de hjemme, sånn at jeg fikk de med meg - hvis jeg ikke orket å dra på skolen og gav meg litt... egentlig veldig mye, sånn ja hjelp da, til à lissom klare å komme meg igjennom bedre.

En av de andre jentene fortalte om sin kontaktlærer:

Hun var veldig rettferdig, forståelsesfull og hun har faktisk gått igjennom depresjon, så hun forstår meg veldig godt. Og hun er bare sånn å veldig positiv energi og veldig hyggelig.

Her beskrives lærerne som strekker seg lenger enn forventet innenfor rollen deres og er villige til å dele av egne erfaringer. Dette er det interessant når vi trekker parallell til kunnskap fra psykisk helsefeltet. Nettopp slike forhold blir trukket fram av brukere av psykisk helsetjenester som viktige for brukernes tilfriskning og bedringsprosesser (Lauveng, 2005; Borg \& Topor, 2013).

\section{AVBRUDDET}

Det er påfallende at kun en av våre informanter selv tok initiativ til å slutte på skolen. I ett av tilfellene var det jentas mor som fremmet forslaget om å slutte på skolen: "Det var egentlig mor som bestemte det, men jeg hadde fortalt henne hvordan jeg hadde det og sånn. Og hun la merke til at det ikke funket lenger'. Ei av de andre visste ikke hvem som hadde bestemt at 
hun skulle slutte:"Jeg vet ikke hvem som bestemte. Jeg mener, jeg har aldri spurt om å kunne slutte selv".

Det var altså i hovedsak rådgiverne og kontaktlærerne på skolen som foreslo å avbryte skolegangen. Det ble som regel begrunnet med at jentene hadde for mye fravær og at det derfor ville være lurt å slutte på videregående slik at de ikke begynte å bruke av «Ungdomsretten». (Ungdomsretten angir rett til inntil 5 år videregående opplæring. Hvis en elev slutter på skolen innen 31. oktober bruker han ikke av ungdomsretten, https://www.vilbli.no/nb/nb/no/nar-bruker-duav-opplaeringsretten-din/a/027310.)

De fant ut at hvis jeg sluttet nå, fikk jeg fortsatt beholde den dere retten til å gå på skole, så da gjorde vi det.

Her er det god grunn til å spørre om ungdomsretten fungerer som en pådriver til å få ungdom ut av skolen istedenfor å arbeide mot fungerende tilretteleggingstiltak.

Jentene ble spurt om de selv hadde noen forslag til hva som kunne ha hjulpet dem før de tok avgjørelsen om å slutte på skolen. Og en gjenganger her er ett ønske om en mer fast oppfølging av helsesøster tidligere i skoleløpet.

En ting jeg skulle ønske var litt annerledes, var at for i løpet av de tre åra så hadde vi en prat med, sånn at alle skulle ha en prat med helsesøster to ganger $i$ løpet av to, tre år. Jeg synes det burde vare litt oftere.

De ønsker også en tettere voksenoppfølging generelt. De savner voksne som jobber sammen mot ett felles miljø på skolene, og ett system som vil fange dem opp dersom de faller utenfor.

Etter at jentene sluttet på videregående ble hverdagen til de fleste preget av "ingenting". "Så da hadde jeg et år da jeg ikke gjorde noen ting egentlig", forteller en av dem. Det lå altså ingen tiltak og ventet når de først hadde avsluttet skolegangen. Oppfølgingstjenesten hadde vært inne og registrert jentene med OTSY-kode, og da var saken regnet som «avklart» og det var opp til dem selv, eventuelt familien å støtte dem videre. På intervjutidspunktet var imidlertid nesten alle tilbake i skolen, og alle hadde håp og drømmer om fremtiden.

\section{DISKUSJON}

Sett $\mathrm{i}$ forhold til samfunnets mål om at ungdommer skal komme gjennom videregående utdanning med en studie- eller yrkeskompetanse kan vi si at jentene $\mathrm{i}$ denne studien har mislyktes. De har opplevd motgang både i hjemmemiljø og skole som synes å ha hatt klar innvirkning på deres frafall fra videregående opplæring (Edvardsen, 2017; Hovland, 2017). Fra et individperspektiv kunne vi si at de ikke har utviklet tilstrekkelig resiliens til å greie å stå i motgang. Her bruker vi imidlertid Ungars (2012) perspektiv på resiliens basert på Bronfenbrenners utviklingsteorier
(Bronfenbrenner, 1979; 2005). Han beskriver resiliens i form av en ligning der resiliens vurderes som både en kvalitet ved interaksjonen mellom barnet og barnets omgivelser og individets individuelle kompetanser ganget med miljøets evne til å stille til rådighet ressurser som er nødvendig for å understøtte barnets velferd (Ungar, 2012).

Det ligger utenfor denne artikkelens ramme å gå inn på informantenes individuelle og forutsetninger. Det vi derimot finner er at det gjennom jentenes skoleløp har oppstått vansker i mesosystemet, altså i samhandling og relasjoner mellom informantene og andre individer i mikrosystemet. Men også ekso- og makrosystemene spiller inn gjennom hvordan skolen er organisert, hvilke mål og verdier den styres etter, hvilke lover, regler og ressurser som er gitt gjennom de politiske systemene. Så istedenfor å snakke om resiliens hos informantene, vil vi gå inn på systemets resiliensgenerende ansvar.

Informantene har sterke historier om mobbing, men her fokuseres det på jentenes opplevelse av mangelen på, eller en uhensiktsmessig reaksjon fra skolens personale. Hadde vi også hørt lærernes tanker om dette, kunne en tenke at de hadde gitt en annen versjon av det som hendte. Dette er imidlertid ikke relevant. Det er jentenes egen erfaring som definerer deres virkelighet og som får de langsiktige konsekvensene slik det tidlig ble definert $\mathrm{i}$ Thomas teorem: "If men define situations as real, they are real in their consequences" (Thomas \& Thomas, 1928, s. 572, etter Levin \& Trost, 2005). Opplæringsloven §9A-2 gir elever på alle nivå i skolen rett til et trygt og godt skolemiljø. Elevens subjektive oppfatning gjelder og skolen har plikt til å handle etter elevens opplevelse (Utdanningsdirektoratet 2017). Rundskrivet som presiserer dette er riktignok relativt nytt, men også da våre informanter begynte sin skolegang var det stor bevissthet og innsats mot mobbing $i$ skolen. Manifest mot mobbing ble lansert av Bondevikregjeringen i 2002 og bidro ifølge skoleforskeren Erling Roland til en kortvarig nedgang i mobbing (Halsan, 2012). Roland sier at for å få varig bedring må fokus på mobbingen opprettholdes (Roland, 2011, Halsan, 2012). Dette vanskeliggjøres når det kommer nye store satsinger i skolen som for eksempel Kunnskapsløftet som ble innført i 2006, på den tiden våre informanter var i starten av sin skolegang.

«Evne til å mestre det sosiale samspillet er av stor betydning, og elevenes sosiale situasjon i skolen er også vesentlig for deres identitetsutvikling og dannelse. Dette gjelder ikke minst for elever som har blitt utsatt for mobbing og krenkelser» (Nordahl et al., 2016 s. 2). Dette sitatet hentet fra en artikkel publisert av Utdanningsdirektoratet understreker skolens ansvar for å gi elevene «kyndighet og modenhet til å møte livet sosialt, praktisk og personlig» slik det heter $\mathrm{i}$ Kunnskapsløftet (Utdanningsdirektoratet 2012 s. 35). Forstått innenfor en utviklingsøkologisk modell, ser vi at på makronivå er det gitt føringer for å ivareta elevene $\mathrm{i}$ forhold til en stor bredde av behov. Læringen 
gjelder ikke bare fag, men også sosial fungering noe som forventes å slå positivt tilbake på den faglige læringen. Skal en få dette til må det arbeides på forskjellige nivå. I eksosystemet må den enkelte skole gjennom sin organisering og verdiformidling opprettholde et fokus på det psykososiale miljøet og legge til rette for gode relasjoner mellom alle parter i meso- og mikrosystemene. Systemene må imidlertid virke sammen. Skolens økonomi legger mye av grunnlaget for hva som skjer i klasserom og skolegård samtidig som samspill mellom skoleledelse og den enkelte lærer må holde fokus på bredden i elevenes behov på en måte som gjør at barna føler seg ivaretatt. Dette har ikke skjedd for våre informanter.

Det ser ut som barneskolen har vært den mest kritiske tiden i våre informanters skoleløp. Når de kommer over i ungdomsskolen har de fleste allerede utviklet omfattende og til dels behandlingstrengende psykososiale vansker. Vi kan ikke tillegge skolen årsaksansvar for dette. Ser vi jentenes vansker i et bioøkologisk perspektiv, finner vi at mange av dem har utfordringer som kan relateres til fysisk sykdom, vansker i familien og svak tilknytning til venner. Dette gir kumulativ risiko og gir svakere grunnlag for utvikling av resiliens. Og jo større motgang et barn møter desto viktigere blir nærmiljøet der skolen er en hovedarena (Ungar, 2013). Flere av jentene forteller om personer som ble viktige for dem i ungdomsskoletiden. Her er det etablert betydningsfulle relasjoner, både til enkeltlærere og til annet personell tilknyttet skolen. Det er interessant å se at til tross for tilbud fra barne- og ungdomspsykiatrien er det personene de møter i skolen som oppfattes som mer hjelpsomme, enten det er en kontakt- eller sosiallærer, miljøterapeut, helsesøster eller kantinelederen. En rekke studier viser at barn og ungdom er tilbakeholdne med å søke psykiatrisk hjelp (Rickwood et al., 2007), men disse ungdommene har hatt et tilbud som de ikke synes de har hatt utbytte av. Dette sier noe om betydningen av samhandling i mikrosystemet. De som er tettest på oppleves å gi den beste støtten, noe som gir grunn til en refleksjon om en henviser barn og unge for raskt til eksterne tjenester istedenfor å sørge for at hjelpen er der de unge selv søker den. En review-studie fra 1999 finner at jo større utfordringer barn og unge har, jo mindre tilfredse er de med det psykiatriske hjelpetilbudet (Hill, 1999). Hill hevder at i mange tilfeller vil det være mer hensiktsmessig å arbeide med de unge gjennom et nettverk de allerede har tillit til. På den måten vil en kanskje komme lenger med å etablere samhandling på mesonivå ved å gi spesialisttjenestene veiledningsansvar mens skolens sosial- og helsepersonale ivaretar den direkte kontakten.

Da våre informanter kom til videregående skole var det med betydelige utfordringer hos de fleste. I en evaluering av Oppfølgingstjenesten fra 1998 definerer Egge fire elevkategorier. Det hun kaller innsatseleven er karakterisert ved at eleven vil ha en utdanning, men greier det ikke uten støttetiltak. Det spesielle med inn- satseleven behøver ikke vare generelle eller spesifikke lareproblemer. Vanskene kan i like stor grad vare personlige problemer, og gi seg utslag i emosjonelle lorevansker (Egge, 1998 s.10). Bare en av våre informanter forteller om spesifikke lærevansker, hos de andre er det emosjonelle eller psykososiale vansker som dominerer. Det er ikke gitt at dette er formidlet til den videregående skolen. Fra et bio-økologisk perspektiv må dette kalles en systemsvikt. Først når problemene ble synlige etter oppstart, kom det forslag om kortere skoledager og færre fag. Dette er imidlertid vanskelig å gjennomføre i praksis. Det hjelper lite med kortere dager hvis det bare går én skolebuss dit en bor. Og når timene er spredt over hele uka slik at eleven må være på skolen hele dagen blir ikke slike tiltak noe reelt alternativ. Da synes det som ett alternativ står igjen, å oppfordre eleven til å slutte. Dette kan ses som et utslag av omtanke. Slutter eleven tidlig nok, bruker hun ikke av Ungdomsretten, dvs. hun har fortsatt rett til fem år i videregående opplæring. Brukt på denne måten blir Ungdomsretten det motsatte av det som er hensikten, sikre ungdom en utdanning. Isteden blir den et middel til eksklusjon. Dette blir et eksempel på hvordan en lovgitt rettighet som altså er initiert $\mathrm{i}$ makrosystemet får en paradoksal virkning når vi fører den ned i mikrosystemet.

Når en ungdom slutter i videregående skole, skal Oppfølgingstjenesten (OT) kobles inn og det skal registreres hvorfor eleven slutter. «Våre» jenter hadde alle OTSY-kode, dvs. de ble definert som for syke til å fortsette på skolen. Når denne koden er satt er saken regnet som avklart, og OT har ikke noe mer ansvar for ungdommen. Konsekvensen av dette er at den unge går ut til «ingenting», altså et system der ingen har ansvar for å følge dem opp. Det gir heller ikke noe bedre grunnlag for å starte opp igjen på et nytt skoleår (Høie $\&$ Thorød, 2018). Ikke har de unge fått tettet faglige hull som antakelig følger med fra ungdomsskolen, og ikke er det noen struktur som har plikt til å fange dem opp og planlegge for nytt forsøk på skolegang. Dermed skyves ansvaret for å komme i gang på nytt ned til den enkelte ungdommen og med de store utfordringene mange av disse har, risikerer vi å miste mange unge mennesker ut av utdanningsløpet. Da kan veien til en uføretrygd være lagt, slik Olsen et al. viste i prosjektet «Et liv jeg ikke valgte» fra 2009.

\section{Avslutning}

For de fleste av våre informanter ble det en rask sorti fra videregående skole. Dette lå ikke i jentenes planer. De ønsket seg en utdanning og til tross for vanskene søkte de fleste seg inn igjen i videregående året etter avbruddet. Om de har lykkes ligger utenfor vår mulighet å svare på. Det vi kan konkludere med er at for disse jentene fikk tilknytningen til skolen en slagside allerede i barneskolen. Vi har belyst deres skolekarriere $\mathrm{i}$ et bio-økologisk- og resiliensperspektiv. I denne sammenhengen var vi ikke ute etter å analysere 
resiliens på individnivå, men har sett etter skolens evne til å være resiliensgenererende ved at systemene trekker i samme retning og arbeider for å støtte opp under barnas utvikling i tråd med skolens formålsparagraf (Opplæringslova, 1998, §1-1). To funn peker seg spesielt ut. Flere av jentene har hatt kontakt med barne- og ungdomspsykiatrien uten å oppleve å ha nytte av dette. De har foretrukket hjelpere knyttet til skolen. Her trenger vi mer forskning om hjelpsomme relasjoner for barn og unge. Vi er også kommet på sporet av at Ungdomsretten har en slagside med å skyve ungdom ut av skolen samtidig som at Oppfølgingstjenesten ikke har oppfølgingsansvar når grunnen til avbruddet synes avklart. På dette feltet må vi få utdypet forskningskunnskap som grunnlag for videre diskusjon om hvordan videregående opplæring skal innrettes $i$ framtida.

\section{TAKK}

Vi retter en stor takk til jentene som ville dele erfaringene sine med oss. Takk også til Oppfølgingstjenestene i Aust- og Vest-Agder for hjelp i rekrutteringsprosessen.

\section{REFERANSER}

Barne-, ungdoms- og familiedirektoratet. (2018). Gjennomføring og frafall i skolen. (Hentet 23.10.18). https:// www.bufdir.no/Statistikk_og_analyse/Oppvekst/Barnehage_og_skole/Gjennomforing_og_frafall_i_skolen/.

Berk, L.E. (2018). Development through the lifespan. Boston: Pearson.

Beyers, J. M., Bates, J.E., Pettit, G.S. \& Dodge K.A. (2003). "Neighborhood structure, parenting processes, and the development of youths' externalizing behaviors: A multilevel analysis." American Journal of Community Psychology 31(1-2): 35-53.

Borg, M. \& Topor, A. (2013). Virksomme relasjoner. Om bedringsprosesser ved alvorlige psykiske lidelser. Oslo: Kommuneforlaget.

Borge, A. I. H. (2010). Resiliens: risiko og sunn utvikling. Oslo, Gyldendal akademisk.

Bronfenbrenner, U. (1979). The ecology of human development: experiments by nature and design. Cambridge, Mass.: Harvard University Press.

Bronfenbrenner, U. (1986). Ecology of the family as a context for human development: Research perspectives. Developmental Psychology 6: 723-742.

Bronfenbrenner, U., (ed). (2005). Making human beings human: bioecological perspectives on human development. The SAGE program on applied developmental science. Thousand Oaks, Calif, Sage Publications.

Bø, I. og Schiefloe, P. M. (2007). Sosiale landskap og sosial kapital: innføring $i$ nettverkstenkning. Oslo, Universitetsforlaget.

Croninger, R., \& Lee, V. (2001). Social capital and dropping out of high school: Benefits to at-risk students of teachers' support and guidance. Teachers College Record, 103(4), 548-581.

De Ridder, K. A. A., Pape, K., Johnsen, R., Holmen, T. L., Westin, S., \& Bjørngaard, J. H. (2013). Adolescent health and high school dropout: a prospective cohort study of 9000 Norwegian adolescents (The YoungHUNT). PloS One, 8(9), e74954.

Edvardsen, S.E. (2017). Hvilke faktorer påvirker unge jenters frafall fra videregående opplcering? Masteroppgave i folkehelse. Kritiansand: Universitetet i Agder.

Egge M. (1998) Hadde det ikke veert for oppfølgingstjenesten ... Samtaleintervjuer med 16 ungdommer. FAFOrapport 241:1998.

Ekeland, T-J. (2011). Ny kunnskap - ny praksis. Et nytt psykisk helsevern. Skien: erfaringskompetanse.no 2011:1

Falch, T., Borge, L.-E., Lujala, P., Nyhus, O. H., \& Strøm, B. (2010). Arsaker til og konsekvenser av manglende fullføring av videregående opplaering (SØF-rapport nr. 03/10). Trondheim: Senter for økonomisk forskning.

Federici, R., \& Skaalvik, E. (2013). Lærer-elev-relasjonen; betydning for elevenes motivasjon og læring. Bedre Skole, (1), 58-63.

Frostad, P., Pijl, S.J. \& Mjaavatn, P.E. (2015). «Losing all interest in school: Social participation as a predictor of the intention to leave upper secondary school early. Scand J Educ Res 59(1): 110-122.

FT-sak 15/35. Arendal: Aust-Agder fylkeskommune.

Halsan, A. (2012). Krever økt fokus på mobbing. Universitetet i Stavanger. Publisert 31.05 .2012 på forskning.no: https://forskning.no/mobbing-skole-og-utdanning/2012/05/krever-okt-fokus-pa-mobbing Hentet 13.07.18.

Hanks, R. S., \& Carr, N. T. (2008). Lifelines of Women in Jail as Self-Constructed Visual Probes for Life History Research. Marriage and Family Review, 42(4), s.105-116.

Haugsgjerd, S., Jensen, P., Karlsson, B. \& Løkke, J.A. (2009). Perspektiver på psykisk lidelse: forstå, beskrive og behandle. Oslo: Gyldendal akademisk.

Hill, M. (1999). "What's the problem? Who can help? The perspectives of children and young people on their well-being and on helping professionals." Journal of Social Work Practice 13(2): 135-145.

Hovland, H. (2017). Bortvalg av videregående skole og mestringstro. Masteroppgave i psykisk helsearbeid. Grimstad: Universitetet i Agder. 
Hughes, J. N. (2012). «Teacher-Student relationships and school adjustment: progress and remaining challenges». Attachment and Human Development, 14(3), 319-327.

Høie, M. M. \& Thorød, A. B. (2018). Alle skal med - ideal eller realitet? I Omdal \& Thygesen: A falle mellom to stoler - samarbeid til barnets beste i barnehage og skole. Oslo, Universitetsforlaget.

Lauveng, A. (2005). I morgen var jeg alltid en løve. Oslo: Cappelen Damm.

Levin, I. og Trost, J. (2005). Hverdagsliv og samhandling - med et symbolsk interaksjonistisk perspektiv. Bergen: Fagbokforlaget.

Lillejord, S., Halvorsrud, K., Ruud, E., Morgan, K., Fryr, T., Fischer-Griffiths, P., . . .\& Manger, T. (2015). Frafall $i$ videregående opplaring: En systematisk kunnskapsoversikt. Oslo: Kunnskapssenter for utdanning.

Masten, A. S. \&. Garmezy, N. (1985). Risk, vulnerability, and protective factors in developmental psychopathology. In: Advances in Clinical Child Psychology, B. B. Lahey and A. E. Kazdin (Eds.). Boston, MA, Springer US: 1-52.

Nordahl, T., Flygare, E. \& Drugli, M.B. (2016) Relasjoner mellom elever. Oslo: Utdanningsdirektoratet (18.03.16, hentet 23.10.18) https://www.udir.no/laring-og-trivsel/skolemiljo/psykososialt-miljo/Relasjoner-mellomelever/Innledning/.

NOU 2015:2. Å høre til. Oslo: Kunnskapsdepartementet (s. 18).

Olsen, T.S, Jentoft, N. \& Jensen, H.C. (2009). «Et liv jeg ikke valgte», Om unge uføre i fire fylker. FOU-rapport nr.9/2009. Kristiansand: Universitetet i Agder og Agderforskning.

Opplæringslova (1998). Lov om grunnskolen og den vidaregåande opplæringa (LOV-1998-07-17-61). Hentet fra https://lovdata.no/dokument/NL/lov/1998-07-17-61.

Rickwood, D., Deane, F. \& Wilson, C. (2007). "When and how do young people seek professional help for mental health problems?" Medical Journal of Australia 187(7 Suppl):S35-9.

Rogstad, J.\& Reegård, K. (2016). De Frafalne: om frafall $i$ videregående opplaring - hvem er de, hva vil de og hva kan gjøres? Oslo, Gyldendal akademisk.

Roland, E. (2011): The broken curve: Effects of the Norwegian manifesto against bullying. International Journal of Behavioral Development, 35 (5): 389-397.

Sabol, T. J. \& Pianta, R. (2012). «Recent Trends in research on teacher-child relationships». Attachment and Human Development, 14(3), 213-231.

Schoon, I. (2012). Temporal and contextual dimensions to individual positive development: A developmentalcontextual systems model of resilience. I Ungar (ed.) The social ecology of recilience. A handbook of theory and practice. New York, Springer: 143-156.

Schoon, I. and J. Bynner (2003). "Risk and Resilience in the Life Course: Implications for Interventions and Social Policies." Journal of Youth Studies 6(1): 21-31.

Schroots, J. J. F., \& Assink, M. H. J. (2005). Portraits of life: Patterns og Events Over the Lifespan. Journal of Adult Development, 12(4): 183.198.

Skaalvik, E. M. \& Skaalvik, S. (2013). Skolen som læringsarena - Selvoppfatning, motivasjon og læring (2. utg.). Oslo: Universitetsforlaget.

Thorød, A. B. (2010). Sosial kapital mellom generasjoner og nærmiljø - en kunnskapsoversikt. I Backe-Hansen \& Hydle: Sosial kapital og andre kapitaler hos barn og unge i Norge. Flervitenskapelige politikk- og forskningsutfordringer. Oslo, Norsk institutt for forskning om oppvekst, velferd og aldring. Rapport nr. 20/10.

Ungar, M. (2011). "The social ecology of resilience: addressing contextual and cultural ambiguity of a nascent construct." Am J Orthopsychiatry 81(1): 1-17.

Ungar, M. (2012). Social ecologies and their contribitions to resilience. I Ungar, M. (ed.), The social ecology of resilience, A handbook of theory and practice. New York, NY: Springer: 13-32.

Ungar, M., Ghazinour, M. \& Richter, J. (2013). "Annual Research Review: What is resilience within the social ecology of human development?" Journal of Child Psychology and Psychiatry 54(4): 348-366.

Utdanningsdirektoratet (2012). Læreplanverket for Kunnskapsløftet. www.Utdanningsdirektoratet.no.

Utdanningsdirektoratet (2016). Kodeverk for Oppfølgingstjenesten (OT) https://www.udir.no/tall-ogforskning/statistikk/Kodeverk-for-oppfolgingstjenesten/ Hentet 12.07.18

Utdanningsdirektoratet (2017). Skolemiljø Udir-3-17. https://www.udir.no/regelverk-og-tilsyn/finnregelverk/etter-tema/Laringsmiljo/skolemiljo-udir-3-2017/3.-en-individuell-rett-til-et-trygt-og-godt-skolemiljo/ Hentet 12.07.18. 